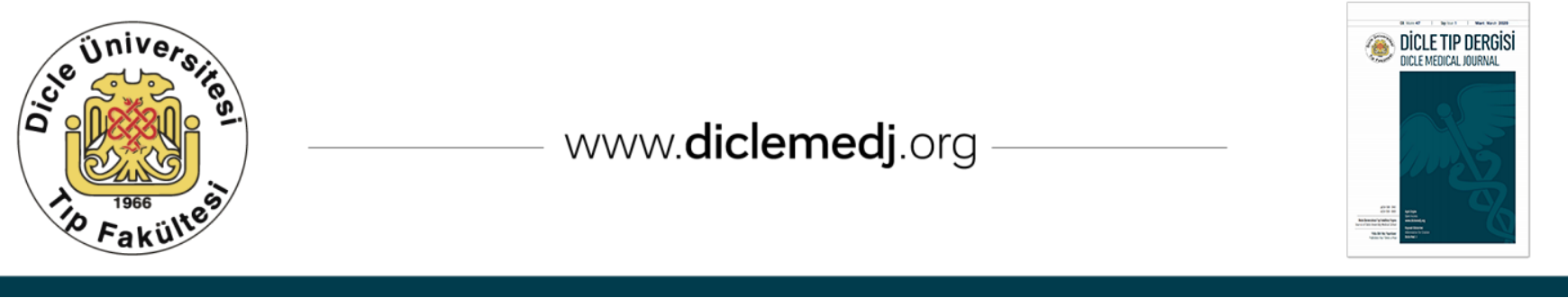

\title{
New Uses of Platelet-Lymphocyte Ratio for Bleeding Risk Stratification in Patients with Nonvalvular Atrial Fibrillation: A Pilot Study
}

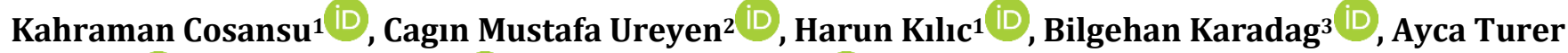 \\ Cabbar $^{4}$ iD , Huseyin Gunduz ${ }^{1}$ iD, Ramazan Akdemir ${ }^{1}$ iD
}

1 Sakarya University, Education and Research Hospital, Deparment of Cardiology, Sakarya, Turkey

2 Antalya Education and Research Hospital, Deparment of Cardiology, Antalya, Turkey

3 Istanbul University, Cerrahpasa Medical Faculty, Deparment of Cardiology, Istanbul, Turkey

4 Yeditepe University Medical Faculty, Deparment of Cardiology, Istanbul, Turkey

Received: 05.08.2019; Revised: 23.12.2019; Accepted: 07.01.2020

\begin{abstract}
Objective: The primary aim of this study was to investigate the role of platelet-lymphocyte ratio (PLR) to predict bleeding risk in nonvalvular atrial fibrillation (NVAF). Secondary aim was to determine the possible relation between PLR and thromboembolic and bleeding risk scores. Tertiary aim was to evaluate the predictive value of PLR for the patients in the therapeutic international normalized ratio (INR) range.

Method: PLR was calculated from the complete blood count of 228 patients who were under warfarin management for NVAF. The patients were called and it was questioned whether they had experienced the bleeding event within six months after measurement of the PLR values.

Results: Bleeding event was observed in 48 patients after the PLR was calculated. It was found significantly correlation between PLR and CHA2DVAS2C $(\mathrm{p}<0.01)$ and HAS-BLED score $(\mathrm{p}<0,001)$. The ROC analysis showed that PLR predicted bleeding with a sensitivity of $83 \%$ and with a specificity of $84 \%$, using a cut-off value of 165,9 . The AUC (area under the curve) for the PLR was found $0.88(\mathrm{p}<0.001)$. PLR predicted the patients in therapeutic INR range with a sensitivity of $75 \%$ at ROC analysis, when using a cut-off value of 125,3 and AUC for the PLR was $0.73(\mathrm{p}<0.001)$. In the multivariate regression analysis, PLR $>165,9$ was determined significant indicator for bleeding $(\mathrm{p}<0.001)$ and showed more than a 12 fold increased risk of bleeding (12.27, [5.74-26.21]).
\end{abstract}


Conclusions: The results of the present study indicate that the PLR might be a useful parameter to detect the risk of bleeding. To our knowledge, this is the first study demonstrating the correlation of PLR with both CHA2DS2-VASc and HAS-BLED risk scores. PLR may also predict the patients within the therapeutic INR range.

Keywords: Platelet-Lymphocyte Ratio, Bleeding Risk, Nonvalvular AF.

\section{Non-Valvuler Atriyal Fibrilasyonu Olan Hastalarda Kanama Risk Sinıflandırılmasında Platelet-Lenfosit Oranının Yeni Kullanımları: Pilot Çalışma}

Öz

Amaç: Bu çalışmanın birincil amacı, PLR'nın NVAF'da kanama riskini tahmin etmedeki rolünü araştırmaktı. İkincil amaç, PLR ile tromboembolik ve kanama riski skorları arasındaki olası ilişkiyi belirlemekti. Üçüncül amaç, terapötik INR aralığındaki hastalar için PLR'nin prediktif değerini değerlendirmekti.

Yöntemler: PLR, non-valvüler AF nedeniyle warfarin tedavisi altında olan 228 hastanın tam kan sayımından hesaplandı. PLR değerlerinin ölçümünden altı ay sonra hastalara telefon edildi ve bu altı ay içinde herhangi bir kanama olayı yaşayıp yaşamadığı sorgulandı.

Bulgular: PLR hesaplandıktan sonra 48 hastada kanama olayı gözlendi. PLR ile CHA2DVAS2C ( $p<0.01$ ) ve HASBLED skorları $(\mathrm{p}<0,001)$ arasında anlamlı bir korelasyon bulundu. ROC analizi, kesim değeri olarak 165,9 alındığında, PLR'nin kanamayı \%83 hassasiyet ve \%84 özgüllük ile tahmin ettiğini göstermiştir. PLR için AUC (eğrinin altındaki alan) 0,88 (p $<0,001$ ) bulundu. ROC analizinde PLR için 125,3 kesme değeri kullanıldığında, PLR \%75 hassasiyetle terapötik INR aralığında bulunan hastaları öngördü ve AUC 0,73 saptandı $(\mathrm{p}<0,001)$. Çok değişkenli regresyon analizinde, PLR> 165,9 değeri kanama için önemli bir gösterge olarak belirlendi ( $\mathrm{p}<0.001)$ ve 12 kattan fazla kanama riski olduğunu gösterdi (12.27, [5.74-26.21]).

Sonuç: Bu çalışmanın sonuçları PLR'nin kanama riskini saptamak için yararlı bir parametre olabileceğini göstermektedir. Bildiğimiz kadarıyla, bu PLR'nin hem CHA2DS2-VASc hem de HAS-BLED risk skorları ile korelasyonunu gösteren ilk çalışmadır. PLR ayrıca terapötik INR aralığındaki hastaları da öngörebilir.

Anahtar kelimeler: Platelet-Lenfosit Oranı, Kanama Riski, Non-Valvüler AF.

\section{INTRODUCTION}

Non-valvular atrial fibrillation (NVAF) is one of the common heart rhythm disorders and is also associated with morbidity and mortality. It is known as an important risk factor for Ischemic Stroke (IS) and Thromboembolism (TE) ${ }^{1}$. Anticoagulation is the most important cornerstone in the treatment of AF. Warfarin treatment may reduce the stroke risk by $60 \%$ to $70 \%{ }^{2}$. However, proper dosing may be hard to provide in clinical practice. Although they are highly effective treatment tools, they are also associated with significant bleeding risks. Bleeding associated with excessive anticoagulation may occur in patients receiving warfarin. The annual incidence of this complication is reported to be between $15-20 \%$, including $1 \%$ to $3 \%$ of fatal bleeding events ${ }^{3}$. Adequate stratification of the risk of thromboembolism and bleeding is also mandatory. The CHA2 DS2-VASc scoring system is widely used to classify the risk of thromboembolism in AF patients. To predict the bleeding risk for individual patients, a various clinical risk estimation tools have been developed and to help distinguish which patients are at low or high risk ${ }^{4}$. HAS-BLED score highlight manageable risk factors to reduce the bleeding risk, has good predictive values ${ }^{5}$.

The pathophysiology of AF is complex and not completely understood. However, inflammation 
has been associated with the onset and continuity of AF and AF-related thrombosis ${ }^{6,7}$. Recent studies have shown that active inflammatory cells and inflammatory mediators may induce a prothrombotic state by promoting endothelial damage / dysfunction and platelet activation in AF patients, thereby linking inflammation and thrombosis ${ }^{6}$.

Platelet-lymphocyte ratio (PLR), defined as the ratio of absolute counts of platelets and lymphocytes. PLR was introduced as an important marker for determining inflammation in cardiovascular diseases. Recently, PLR has been found to correlate positively with inflammatory markers including tumor necrosis factor- $\alpha$ (TNF- $\alpha$ ) and interleukin (IL)-6 in cardiac and noncardiac patients ${ }^{8,9}$. PLR was also shown to be correlate positively with serum CRP level as a conventional marker for systemic inflammation ${ }^{10}$. The calculation of PLR is a relatively simple and inexpensive method when compared to other inflammatory cytokines.

The primary purpose of the present study was to evaluate the role of PLR to predict bleeding risk in NVAF. Secondary aim was to determine the possible relation between PLR and tromboembolic and bleeding risk scores. Tertiary aim was to investigate the predictive role of PLR in patients within the therapeutic INR range.

\section{METHODS}

\section{Study Population}

This was a single-center cohort study. A total of 228 nonvalvular AF patients who had been taking warfarin for more than 3 months and admitted to our outpatient cardiology clinic in Sakarya University Education and Research Hospital, Sakarya, Turkey for routine INR examination were included in the present study. All patients were evaluated for age, gender, DM, hypertension, stroke history, smoking status, chronic heart failure and chronic renal failure.
Patients over 18 years of age who applied to the cardiology outpatient clinic and used warfarin for non-valvular AF was included to the study. Exclusion criteria included valvular heart disease, autoimmune diseases, ongoing infection or systemic inflammatory conditions, acute congestive heart failure, acute renal failure, acute coronary syndrome, acute stroke, cancer. Patients with high CRP values were also excluded. Valvular heart disease was defined as rheumatic mitral stenosis, a mechanical or bioprosthetic heart valve or mitral valve repair, based on the definition of "non-valvular" AF in the 2014 American College of Cardiology, American Heart Association, and Heart Rhythm Society guideline ${ }^{11}$. Six months after the measurement of the PLR values, the patients were called and it was questioned whether they had experienced the bleeding event.

The HAS-BLED and CHA2DS2-VASc scores were calculated by examination of the medical records. AF patients were divided into two groups according to CHA2DS2-VASc thromboembolic risk scoring system; lowintermediate risk group ( 0 or 1 ) and high-risk group ( $\geq 2)$. AF patients also divided into two groups according to HAS-BLED bleeding risk scoring system; low- intermediate bleeding risk (score $<3$ ) and high bleeding risk (score $\geq 3$ ) group.

Recent transthoracic echocardiography examinations (performed within last 2 months) were assessed for each patient from medical records. A new echocardiographic examination was performed for patients without recent echocardiographic data. Left ventricular ejection fraction (LVEF) was measured by modified Simpson's method.

This study complied with the Declaration of Helsinki, and it was approved by the independent medical ethics committee of Sakarya University Education and Research Hospital. 


\section{Laboratory Parameters}

Platelet and lymphocyte counts were obtained from complete blood count. PLR was measured by dividing platelet count by lymphocyte count. The INRs and other parameters of patients were taken from medical records on hospital system.

\section{Statistical Analysis}

The Statistical Package for the Social Sciences (SPSS) 16.0 for Windows was used for the statistical analysis. The categorical data were expressed as percentage, and continuous data were expressed as mean \pm standard deviation. Continuous variables were tested by the Kolmogorov-Smirnov test for determine normal distribution. Comparisons between groups were made using the Fisher's exact or chi-square tests for qualitative variables. The independent $t$-test was performed for normally distributed continuous variables and the MannWhitney U test was performed for non-normally distributed continuous variables. Correlation analyses were performed using a Spearman correlation test between parametric variables. Multivariate regression analysis was used to investigate the indicators of bleeding risk. Results of regression analysis are reported as mean (SD) and percentage or hazard ratio (HR) (95\% CI). Receiver operating characteristic analysis (ROC) was used to assess the ability of the PLR to predict patients who was in the therapeutic INR range and the ideal cutoff value of PLR. A P-value of $<0.05$ was considered significant.

\section{RESULTS}

There was 228 patients included in the present study. Baseline demographic and laboratory characteristics of the patient group were presented in Table I.
Table I: Baseline demographic, clinical and laboratory characteristics of study group.

\begin{tabular}{|l|c|}
\hline Age (Years) & $70.25 \pm 9.35$ \\
\hline Female, [n (\%)] & $138(60.5)$ \\
\hline HT [n (\%)] & $144(63.2)$ \\
\hline DM [n (\%)] & $70(30.7)$ \\
\hline HPL [n (\%)] & $48(21.1)$ \\
\hline CVD [n (\%)] & $30(13.2)$ \\
\hline PAD [n (\%)] & $6(2.6)$ \\
\hline PE [n (\%)] & $5(2.2)$ \\
\hline Bleeding [n (\%)] & $48(21.1)$ \\
\hline PLR & $147.46 \pm 69.43$ \\
\hline LVEF (\%) & $54.72 \pm 11.36$ \\
\hline PASP (mmHg) & $28.18 \pm 14.32$ \\
\hline Creatinin (mg/dl) & $1.04 \pm 0.27$ \\
\hline PT & $25.58 \pm 10.59$ \\
\hline aPTT & $37.28 \pm 9.94$ \\
\hline INR & $2.59 \pm 1.61$ \\
\hline CHA2DVAS2C & $3.32 \pm 1.31$ \\
\hline HASBLED & $2.28 \pm 1.04$ \\
\hline Note: Data are presented & \\
\hline
\end{tabular}

Note: Data are presented as mean \pm standard deviation.

Abbreviations: HT, Hypertension; DM, Diabetes mellitus; HPL, Hyperlipidemia; CVD, Cerebrovascular Disease; PAD, Periferic Arterial Disease; PE, Pulmonary Embolia; PLR, Platelet Lymphocite Ratio; LVEF, Left Ventricular Ejection Fraction; PASP, Pulmonary Artery Sistolic Pressure; PT, Prothrombin Time; aPTT, activated Partial Thromboplastin Time; INR, International Normalized Ratio.

The mean age was $70.25 \pm 9.35$. Female gender comprised $60.5 \%$ of the patients. In the present study mean CHA2DS2-VASc score was calculated $3.32 \pm 1.31$ and mean HASBLED score was found $2.28 \pm 1.04$. One hundred and seven (\%47) patients was in the therapeutic INR range. The comparison of demographic, clinical and laboratory characteristics of patients with and without bleeding was presented in Table II. 
Table II. The comparison of patients with and without bleeding.

\begin{tabular}{|c|c|c|c|}
\hline Variables & $\begin{array}{c}\text { Patients with } \\
\text { bleeding } \\
\text { (n=48) }\end{array}$ & $\begin{array}{c}\text { Patients without } \\
\text { bleeding } \\
\text { (n=180) }\end{array}$ & p-value \\
\hline Age, years & $72.8 \pm 8.8$ & $69.5 \pm 9.3$ & .030 \\
\hline Female, [n (\%)] & $31(64.5)$ & $107(59.4)$ & .389 \\
\hline HT [n (\%)] & $34(70.8)$ & $110(61.1)$ & .129 \\
\hline DM [n (\%)] & $12(25.0)$ & $58(32.2)$ & .391 \\
\hline HPL [n (\%)] & $7(14.5)$ & $41(22.7)$ & .208 \\
\hline CVD [n (\%)] & $9(18.7)$ & $21(11.6)$ & .234 \\
\hline Non-steroid or & $5(10.4)$ & $18(10.0)$ & .889 \\
\hline ASA & $53.9 \pm 13.3$ & $55.0 \pm 10.6$ & .682 \\
\hline LVEF (\%) & $1.16 \pm 0.44$ & $1.01 \pm 0.21$ & .111 \\
\hline Creatinin (mg/dl) & $26.2 \pm 9.0$ & $25.4 \pm 10.9$ & .610 \\
\hline PT & $39.1 \pm 10.3$ & $36.7 \pm 9.8$ & .146 \\
\hline aPTT & $2.64 \pm 1.20$ & $2.57 \pm 1.70$ & .790 \\
\hline INR & $3.59 \pm 1.24$ & $3.25 \pm 1.33$ & .120 \\
\hline CHA2DVAS2C & $2.85 \pm 1.17$ & $2.13 \pm 0.95$ & $<.001$ \\
\hline HASBLED & $227.8 \pm 94.5$ & $126.5 \pm 40.8$ & $<.001$ \\
\hline PLR & (n) & \\
\hline
\end{tabular}

Note: Data presented as mean \pm standard deviation.

Abbreviations: HT, Hypertension; DM, Diabetes Mellitus; HPL, Hyperlipidemia; CVD, Cerebrovascular Disease; ASA, AcetylSalicylic-Acid; LVEF, Left Ventricular Ejection Fraction; PT, Prothrombin Time; aPTT, activated Partial Thromboplastin Time; INR, International Normalized Ratio; PLR, Platelet count / Lymphocyte Ratio (/mm3).

Bleeding was observed in fourty eight patients within 6 months after the PLR was calculated. None of the bleedings were major bleeding. Age and HAS-BLED scores were found significantly higher in the bleeding group ( $\mathrm{p}$ : $0.03, \mathrm{p}<0.001$, respectively). Likewise, PLR was significantly higher in the bleeding group $(\mathrm{p}<0.001)$. There was no statistical difference between the groups in terms of concomitant non-steroid or acetylsalicylic-acid use.

We researched correlation between PLR values and CHA2DS2-VASc and HASBLED scores and found significantly correlation between PLR and CHA2DS2-VASc ( $\mathrm{r}$ : 0.189; $\mathrm{p}<0.01$ ) and HASBLED score ( $r: 0,449 ; \mathrm{p}<0.001)$ (Table III).
Table III. Correlation table of PLR with various factors.

\begin{tabular}{|l|c|c|}
\hline & $\boldsymbol{r}$ & $\boldsymbol{p}$ \\
\hline CHA2DVAS2C & .189 & .004 \\
\hline HASBLED & .449 & $<.001$ \\
\hline LVEF & .147 & .136 \\
\hline CREATININ (mg/dl) & -.007 & .931 \\
\hline INR & .089 & .180 \\
\hline
\end{tabular}

Abbreviations: $L V E F$, left ventricular ejection fraction; INR, international normalized ratio.

Significantly higher PLR values were shown in patients with high-risk CHA2DS2-VASc score group than low-moderate risk group (150.6 \pm 70.3; $110.6 \pm 44.5 ; \mathrm{p}=0.019$ ) (Table IV).

Table IV. The comparison of high risc CHA2DS2-VASc group with low-intermediate group.

\begin{tabular}{|c|c|c|c|}
\hline Variables & $\begin{array}{c}\text { High } \\
\text { CHA }_{2} \text { DS}_{2} \text {-VASc } \\
\text { group } \\
(\mathbf{n = 2 1 0 )}\end{array}$ & $\begin{array}{c}\text { Low- } \\
\text { intermediate } \\
\text { CHA }_{2} \text { DS}_{2} \text {-VASc } \\
\text { group } \\
\text { (n=18) }\end{array}$ & $p$-value \\
\hline Age, years & $70.8 \pm 9.4$ & $63.8 \pm 5.2$ & $<.001$ \\
\hline $\begin{array}{c}\text { Female, [n } \\
(\%)]\end{array}$ & $132(62.9)$ & $6(33.3)$ & .014 \\
\hline HT [n (\%)] & $142(67.6)$ & $2(11.1)$ & $<.001$ \\
\hline DM [n (\%)] & $70(33.3)$ & $0(0.0)$ & $<.001$ \\
\hline LVEF (\%) & $54.6 \pm 11.5$ & $56.6 \pm 2.8$ & .765 \\
\hline $\begin{array}{c}\text { Creatinin } \\
\text { (mg/dl) }\end{array}$ & $1.04 \pm 0.27$ & $0.97 \pm 0.29$ & .582 \\
\hline INR & $2.60 \pm 1.66$ & $2.41 \pm 0.57$ & .623 \\
\hline PLR & $150.6 \pm 70.3$ & $110.6 \pm 44.5$ & .019 \\
\hline
\end{tabular}

Note: Data presented as mean \pm standard deviation.

Abbreviations: HT, Hypertension; DM, Diabetes Mellitus; LVEF, Left Ventricular Ejection Fraction; INR, International Normalized Ratio; PLR, Platelet count / Lymphocyte Ratio (/mm3).

There was a progressive increase in PLR with respect to HASBLED scores (Figure 1).

There was also significant difference between high risk HASBLED group with lowintermediate group in terms of PLR $(170.78 \pm 90.37 ; \quad 132.81 \pm 46.92 ; \quad \mathrm{p}<0.001)$ (Table V). 


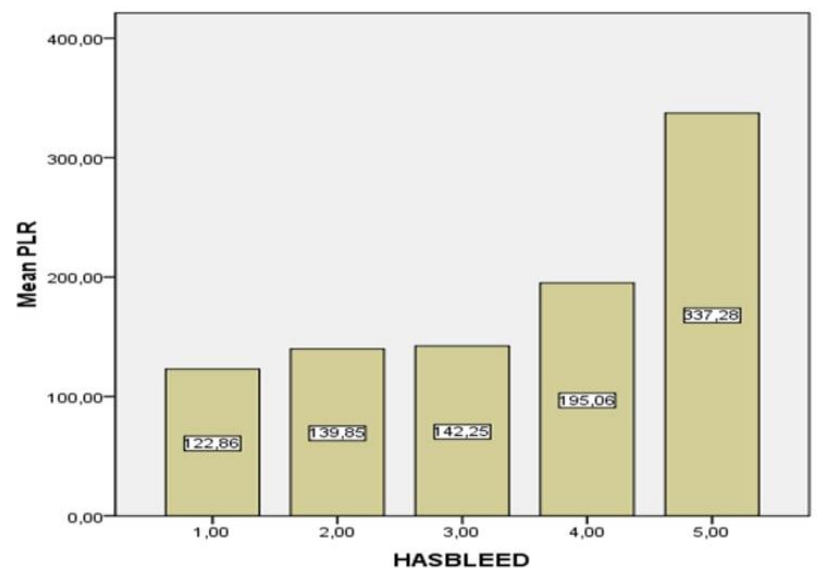

Figure 1: Relation of PLR value and HASBLED score.

Table V. The comparison of high risc HASBLED group with low-intermediate group.

\begin{tabular}{|c|c|c|c|}
\hline Variables & $\begin{array}{c}\text { High } \\
\text { HASBLED group } \\
\text { (n=88) }\end{array}$ & $\begin{array}{c}\text { Low- } \\
\text { intermediate } \\
\text { HASBLED group } \\
\text { (n=140) }\end{array}$ & p-value \\
\hline Age & $74.6 \pm 7.3$ & $67.4 \pm 9.4$ & $<.001$ \\
\hline Female, [n (\%)] & $52(59.1)$ & $86(61.4)$ & .727 \\
\hline HT [n (\%)] & $70(79.5)$ & $74(52.9)$ & $<.001$ \\
\hline DM [n (\%)] & $30(34.1)$ & $40(28.6)$ & .381 \\
\hline LVEF (\%) & $52.3 \pm 13.2$ & $56.8 \pm 8.9$ & .051 \\
\hline Creatinin & $1.15 \pm 0.35$ & $0.96 \pm 0.16$ & $<.001$ \\
\hline (mg/dl) & $2.74 \pm 2.36$ & $2.49 \pm 0.83$ & .330 \\
\hline INR & $170.7 \pm 90.3$ & $132.8 \pm 46.9$ & $<.001$ \\
\hline PLR &
\end{tabular}

Note: Data presented as mean \pm standard deviation.

Abbreviations: HT, Hypertension; DM, Diabetes Mellitus; LVEF, Left Ventricular Ejection Fraction; INR, International Normalized Ratio; PLR, Platelet count / Lymphocyte Ratio (/mm3).

Female patients had significantly higher PLR $(160.29 \pm 73.70$ vs $127.80 \pm 57.35 ; \mathrm{p}<0.001)$ but no difference was seen in comparison to males in terms of CHA2DS2-VASc and HASBLED risk scores.

The ROC analysis showed that PLR predicted bleeding with a sensitivity of $83 \%$ and with a specificity of $84 \%$, using a cut-off value of 165,9 . AUC (area under the curve) for PLR in ROC analysis was found 0.88 (95\% CI, 0.82-0.94; p $<0.001$ ). (Figure 2).

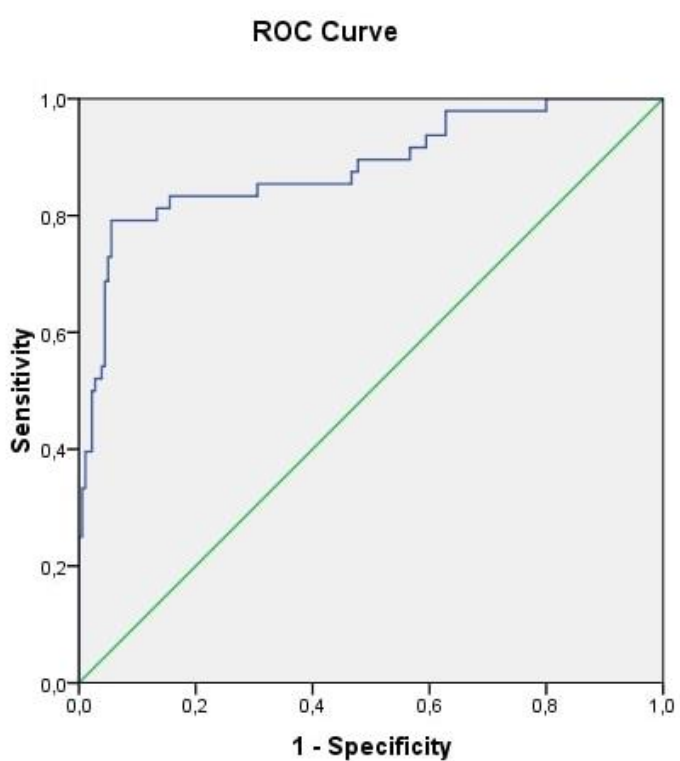

Figure 2: The sensitivity and specificity of PLR (platelet to lymphocyte ratio) for prediction of the bleeding.

In an another ROC analysis, PLR predicted the patients in therapeutic INR range with a sensitivity of $75 \%$ and with a specificity of $62 \%$, using a cut-off value of 125,3 . The AUC for the PLR was found 0.73 (95\% CI, 0.66-0.79; p< 0.001) (Figure 3).

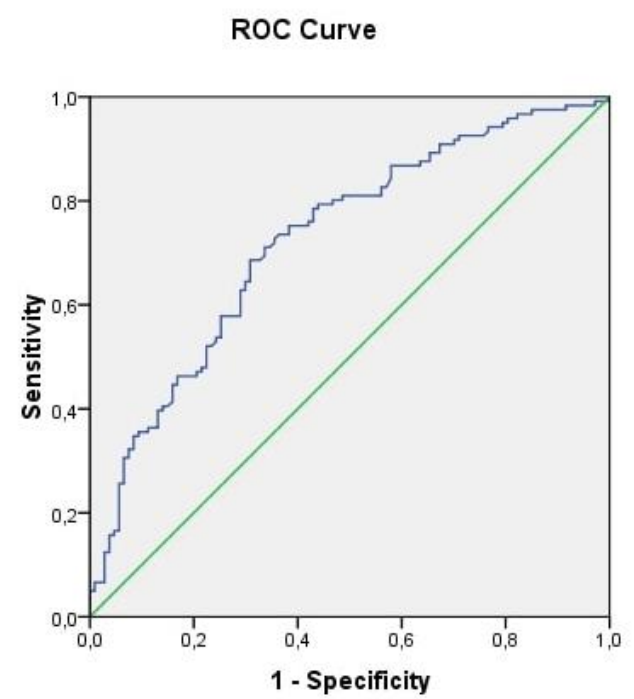

Diagonal segments are produced by ties.

Figure 3: The sensitivity and specificity of PLR (platelet to lymphocyte ratio) for prediction of the INR in therapeutic range. 
On multivariate regression analysis (reported as $\mathrm{HR}[95 \% \mathrm{CI}])$, significant indicator for bleeding was PLR $(\mathrm{p}<0.001)$. Patients with PLR $>165,9$ had more than a 12-fold increased risk of bleeding (12.27, [5.74-26.21]). It was also found that low-intermediate HASBLED group had $45 \%$ lower risk than high HASBLED risk group for developing bleeding event $(0.55$ [95\% CI, 0.31-0.99] ( $\mathrm{p}=0.04)$.

\section{DISCUSSION}

This study consists of NVAF patients who were admitted to the cardiology outpatient clinic and receiving warfarin. The results revealed that PLR is a significant indicator for bleeding in patients with NVAH. This study demonstrate that there is a significant correlation between the PLR with bleeding and thromboembolic risk scores. The PLR is a predictive indicator of patients within the therapeutic INR range.

NVAF is the most common sustained arrhythmia with high prevalence, especially in the elderly population ${ }^{1}$. NVAF is associated with significant morbidity and mortality, particularly due to thromboembolism and stroke ${ }^{5}$. The underlying pathophysiology of NVAF is complex and not fully resolved. The previous studies have established a strong relationship between atrial fibrillation and inflammation. One of the inflammatory pathways underlying $\mathrm{AF}$ is leukocyte activation ${ }^{12}$. Also activated platelets precipitate to produce inflammatory substances from endothelial cells and leukocytes that cause monocyte adhesion and transmigration and thereby enhancing the inflammatory process ${ }^{13,14}$. In previous studies, major adverse cardiovascular outcomes were associated with higher platelets and lower lymphocyte counts. Gary et al. reported that higher platelet volume may change blood viscosity and increase inflammation ${ }^{15}$. Davi et al. concluded that higher platelet activity was associated with higher rates of cardiovascular events $^{16}$. Furthermore, platelet counts were found to be associated with short and long term mortality in patients with ST-elevated and nonST elevated MI and unstable angina pectoris ${ }^{17,18}$. It was also documented that fibrinogen levels and platelet counts are correlated positively and associated to inflammation in acute coronary syndrome patients.

Several studies have investigated the association of PLR with bleeding in various diseases. Zou et al reported that PLR was associated with gastrointestinal hemorrhage in patients with acute cerebral haemorrhage ${ }^{19}$. In an another study, the mean PLR value of the pediatric recurrent epistaxis group was statistically higher than the control group ${ }^{20}$. In the study carried out by Gayret et al, PLR of the patients with gastrointestinal bleeding were found to be significantly increased compared to those without bleeding ${ }^{21}$. On the other hand, there are only few clinical trials demonstrating an association between PLR and atrial fibrillation, but none of them is related to bleeding. Saskın et al. revealed that the preoperative high platelet to lymphocyte ratio was independent risk factor for occurrence of atrial fibrillation in the postoperative early period $^{22}$. In patients with paroxysmal atrial fibrillation, a higher PLR has been documented to be significantly associated with the presence of silent brain infarction (SBI). On the contrary, no significant relationship was found between CHA2DS2-VASc scores and presence of SBI in this study ${ }^{23}$.

Determining of risk factors for bleeding complications in warfarin patients would allow identification of patients at risk. In the present study; age, drugs with concomitant use that interfere with haemostasis (aspirin or nonsteroidal anti-inflammatory drugs), HASBLED score and PLR were significantly higher in bleeding group while they are receiving warfarin treatment. In previous studies, bleeding rates were found different in patients receiving warfarin treatment depending on the 
characteristics of the study group. Monteiro et al found that the annual incidence of minor bleeding was $17.7 \%{ }^{24}$. Oztürk et al reported that $33.3 \%$ of the patients had experienced minor and/or major bleeding at least once during 1year period, moreover bleeding complications detected in $38.9 \%$ of patients $\geq 65$ years of age and in $26.2 \%$ of patients $<65$ years of age ${ }^{25}$. A recent study showed that the clinically relevant minor bleeds and severe bleeding events were found $66.7 \%$ in the warfarin treatment group during the two-year follow-up ${ }^{26}$. In the present study, minor bleeding rate was found $21.1 \%$. The association of PLR with bleeding was investigated for the first time in this study, and it was shown that PLR is an independent risk factor for minor bleeding.

Our study revealed that CHA2DS2-VASc score was positively correlated with PLR. This finding suggests that PLR might be associated with the thromboembolic risk exhibited by CHA2DS2VASc score in patients with nonvalvular $\mathrm{AF}^{27}$. At the same time in our study higher PLR was found to be associated with a high CHA2DS2VASc score. In accordance with these findings, our study also showed a significant positive correlation between PLR and HASBLED score. Increased PLR levels consistent with the gradual increase in the HASBLED score suggest that PLR may have a predictive role for bleeding risk. The association between PLR and CHA2DS2-VASc and HASBLED scores was determined for the first time with our study. The detection of bleeding events with high sensitivity and specificity by the PLR is another important finding in this study. In addition, PLR values above 165.9 were associated with more than 12-fold increased risk of bleeding.

INR values lower than 2.0 contribute to the increased risk of embolic stroke, whereas high INR values greater than 3.0 contribute to the increased risk of bleeding. In the present study we found that PLR may predict the INR value in the therapeutic range with $75 \%$ sensitivity. This result can be explained as high PLR value may contribute to prediction of increased risk of stroke and bleeding. In our study, correlations of the PLR with CHA2DS2-VASc and HASBLED risk scores may also support this result.

Female gender is one of the paramater of CHA2DS2-VASc score. In the present study although female gender's CHA2DS2-VASc and HASBLED scores were not different from men, PLR was found to be significantly higher in female gender. Depending on this result, it may be suggested that females may have more risk for stroke and bleeding than men.

\section{CONCLUSION}

The results of the present study indicates that, PLR is important variable for determining patient's minor bleeding complications while they are receiving anticoagulation treatment. INR needs to be more closely monitored among patients whose PLR $>165,9$ on warfarin treatment. To our knowledge, this is the first study to demonstrate a correlation between PLR and CHA2DS2-VASc and HASBLED risk scores. PLR has been found to be closely related to both scoring systems, therefore we suggest that PLR may be used as a simple and inexpensive adjunct to CHAD2S2-VASc and HASBLED scores to predict thromboembolic and bleeding risks. PLR may also be useful to predict the patients within the therapeutic INR range. These results are encouraging regarding the use of the PLR in risk prediction in NVAF as an inexpensive, readily available, and practical parameter. Other large-scale, randomized studies are needed to clarify the role of the PLR in the pathophysiology of NVAF.

\section{LIMITATIONS}

The primary limitation of the present study is retrospective design. Furthermore, current study is based on a single-center experience and the sample size was relatively small. Moreover, other inflammatory markers such as TNF- $\alpha$, 
high-sensitivity CRP, interleukins and chemokines were not addressed in this study.

\section{FOOTNOTES}

This research did not receive any specific grant from funding agencies in the public, commercial, or not-for-profit sectors.

Ethics Committee Approval: This study complied with the Declaration of Helsinki, and it was approved by the independent medical ethics committee of Sakarya University Education and Research Hospital.

Declaration of Conflicting Interests: The authors declare that they have no conflict of interest.

Financial Disclosure: No financial support was received.

\section{REFERENCES}

1. Lin HJ, Wolf PA, Kelly-Hayes M, et al. Stroke severity in atrial fibrillation. The Framingham Study. Stroke. 1996; 27: 1760-4.

2. Hart RG, Pearce LA, Aguilar MI. Meta-analysis: antithrombotic therapy to prevent stroke in patients who have nonvalvular atrial fibrillation. Ann Intern Med. 2007; 146: 857-67.

3. Zareh M, Davis A, Henderson S. Reversal of warfarin-induced hemorrhage in the emergency department. West J Emerg Med. 2011; 12: 386-92.

4. Beyth RJ, Quinn LM, Landefeld CS. Prospective evaluation of an index for predicting the risk of major bleeding in outpatients treated with warfarin. Am J Med. 1998; 105: 91-9.

5. Camm AJ, Lip GY, De Caterina R, et al. 2012 focused update of the ESC guidelines for the management of atrial fibrillation: an update of the 2010 ESC guidelines for the management of atrial fibrillation. Developed with the special contribution of the European Heart Rhythm Association. Eur Heart J 2012; 33: 2719-47.
6. Watson T, Shantsila E, Lip G.Y. Mechanisms of thrombogenesis in atrial fibrillation: Virchow's triad revisited. Lancet. 2009; 373: 155-66.

7. Prage $P$, Hisham D, Peter T, et al. Update on the association of inflammation and atrial fibrillation. J Cardiovasc Electrophysiol. 2010; 21: 1064-70.

8. Turkmen K, Erdur FM, Ozcicek F, et al. Platelet-to-lymphocyte ratio better predicts inflammation than neutrophil-to-lymphocyte ratio in end-stage renal disease patients. Hemodial Int. 2013; 17: 391-6.

9. Turkmen K. Platelet-to-Lymphocyte Ratio: One of the novel and valuable platelet indices in hemodialysis patients. Hemodial Int. 2013; 17: 670.

10. Akboga MK, Canpolat U, Balci KG, et al. Increased Platelet to Lymphocyte Ratio is Related to Slow Coronary Flow. Angiology. 2016; 67: 21-6.

11. January CT, Wann LS, Alpert JS, et al. 2014 AHA/ACC/HRS guideline for the management of patients with atrial fibrillation: a report of the American College of Cardiology/American Heart Association Task Force on Practice Guidelines and the Heart Rhythm Society. J Am Coll Cardiol. 2014; 64: e1-e76.

12. Friedrichs K., Klinke A., Baldus S. Inflammatory pathways underlying atrial fibrillation. Trend Molec Med. 2011; 17: 556-63.

13. Gawaz $M$, Langer $H$, May AE. Platelets in inflammation and atherogenesis. J Clin Invest. 2005; 115: 3378-84.

14. Lindemann $S$, Krämer $B$, Seizer $P$, et al. Platelets, inflammation and atherosclerosis. J Thromb Haemost. 2007; 5: 203-11

15. Gary T, Pichler M, Belaj K, et al. Platelet-tolymphocyte ratio: a novel marker for critical limb ischemia in peripheral arterial occlusive disease patients. PLoS One. 2013; 8: 676-88. 
16. Davi G, Patrono C. Platelet activation and atherothrombosis. N Engl J Med. 2007; 357: 2482-94.

17. Ly HQ, Kirtane AJ, Murphy SA, et al. Association of platelet counts on presentation and clinical outcomes in ST-elevation myocardial infarction (from the TIMI Trials). Am J Cardiol. 2006; 98: 1-5.

18. Slavka G, Perkmann T, Haslacher H, et al. Mean platelet volume may represent $a$ predictive parameter for overall vascular mortality and ischemic heart disease. Arterioscler Thromb Vasc Biol. 2011; 31: 12158.

19. Zou Y, Zhang W, Huang C, Zhu Y. Clinical significance of neutrophil to lymphocyte ratio and platelet to lymphocyte ratio in acute cerebral hemorrhage with gastrointestinal hemorrhage, and logistic regression analysis of risk factors. Exp Ther Med. 2019; 18: 1533-8.

20. Aksakal C, Şahin M. Evaluation of neutrophil/lymphocyte ratio and platelet/lymphocyte ratio in recurrent epistaxis in childhood: case controlled study. Pan Afr Med J. 2019; 32: 154.

21. Gayret OB, Erol M, Tekin Nacaroglu H. The Relationship of Neutrophil-Lymphocyte Ratio and Platelet-Lymphocyte Ratio with Gastrointestinal Bleeding in Henoch-Schonlein Purpura. Iran J Pediatr. 2016; 26: e8191.
22. Şaşkın H, Düzyol C, Özcan $\mathrm{KS}$, et al. Preoperative Platelet to Lymphocyte Ratio Is Associated with Early Morbidity and Mortality after Coronary Artery Bypass Grafting. Heart Surg Forum. 2015; 18: E255-62.

23. Altintas 0 , Tasal A, Niftaliyev $E$, et al. Association of platelet-to-lymphocyte ratio with silent brain infarcts in patients with paroxysmal atrial fibrillation. Neurol Res. 2016; 21: 1-6.

24. Monteiro JMC, San-Martin DL, Silva BCG, et al. Dabigatran and warfarin in nonvalvular atrial fibrillation or atrial flutter in outpatient clinic practice in Brazil. Arq Neuropsiquiatr. 2019; 77: 80-3.

25. Ozturk M, Ipekci A, Kiyak SK, et al. Bleeding Complications in Warfarin-Treated Patients Admitted to the Emergency Department. J Clin Med Res. 2019; 11: 106-13.

26. Ng DL, Gan GG, Chai CS, et al. Comparing quality of life and treatment satisfaction between patients on warfarin and direct oral anticoagulants: a cross-sectional study. Patient Prefer Adherence. 2019; 13: 1363-73.

27. Akdag S, Simsek H, Sahin M, et al. Association of epicardial adipose tissue thickness and inflammation parameters with CHA2DS2VASASc score in patients with nonvalvular atrial fibrillation. Ther Clin Risk Manag. 2015; 11: 1675-81. 